\title{
Construction of Emotional Intelligence Gamers in Win Game DOTA2
}

\author{
Y Hereyah ${ }^{1}$, S M P Darmawan ${ }^{2}$ \\ ${ }^{1,2}$ Univeritas Mercu Buana \\ 1yoyoh.hereyah@mercubuana.ac.id, ${ }^{2}$ Sandrina mpd@gmail.com
}

\begin{abstract}
Dota 2 is a strategic action game that was exceptionally competitive. This research began with the Difficulties of winning on Dota 2 is an interesting phenomenon. To win Dota 2, players will need good strategy and teamwork apart from skills. A good communication skills between team mates are also important to win this game. This research's objective is to find how social construction and communication pattern between team mates are also important to win Dota 2. This research uses qualitative methods with Alfred Schutz, phenomenology approach. The conclusion of this research are the original Dota 2 players had motive to have fun while playing and Also friends motive, achievement motive and Income motive. Players are Able to express themselves, acquire profit and pride, players acquire Also emotional intelligence by playing Dota 2 .
\end{abstract}

Keywords: DOTA 2, Games, Communication Pattern, Phenomenlogy

\section{INTRODUCTION}

Dota 2 is an action game and an exceptionally competitive strategy. Game Dota 2 was played in a professional and enjoyed by millions of people in the world and Indonesia by selecting hundreds of Hero and formed two teams of five players to win the game by destroying the enemy region. This game is very attractive to many players DOTA 2 (Gamers) where they play games DOTA 2 in addition to getting a lot of experience in making friends and they also have a chance to win a prize of winning tournament. The interest this study originated is from an interesting phenomenon where winning the game DOTA 2 was not easy. Win the game DOTA 2 is not just rely on the ability of regular play but also takes a good strategy and good teamwork. Besides, it also needed the ability of good communication between team to be winning the game DOTA 2. The players were varied. Various motives appear why a player decided play DOTA 2. From the variety of motives, the players still have one goal which is to win the game DOTA 2.

In Dota 2 online game itself, the game has become an addiction for the players. Researchers often find the phenomenon, many players are willing to spend time and countless money in this game. The researchers also found that a victory in this game is very important for the players Dota 2. The phenomenon that occurs is when many gamers difficulties in communicating with each other for many players forget the meaning of cooperation so that the victory is unlikely. Because the game Dota 2 is a game that consists of 5 people per game against five people who have different characteristics and different minds of the players who made the game Dota 2 is very difficult to win.

Patterns of communication among online game players is an experience of life and reality that appears and occurs among online game players who has the nature and significance, 
especially in order to win a match online game Dota 2 Dota 2 . The popularity until recently has been generating a lot of community players online. For winning the game DOTA 2 required good teamwork, where the game DOTA 2 in the main right by five (5) players against five (5) players. Not just playing in areas of the opponent but the game DOTA 2 also requires players to think to make a strategy to defeat the opponent. In addition to using the ability to play, players must also have good teamwork in the game.

The focus of this research is What factors are affecting the Emotional Intelligence Gamers In Win Game Dota2. Computer Mediated Communication, Computer Mediated Communication (CMC) is a term used for communication between two or more people to interact via a different computer. Or by John December (1997) Co puter Mediated commnication is a human process communicates with a computer via.

In today's era of information technology, communication mode in which we live has been mediated by the Internet and has been moving quickly toward what is called computermediated communication (CMC) or computer-mediated communication. In this context, Computer-mediated communication (CMC) is seen as the integration of computer technology with our lives. Computer Mediated Communication (CMC) is a term used for communication between two or more people to interact via a different computer. Or by John December (1997) Computer Mediated Commnication is human processes communicate using via computer, with the involvement of a person, in a situation of a particular context, to be involved in the process to form the media as the destination.

Development of Internet technology requires people to use the computer as a medium of information. Make the converging Internet is divided into three sections one of which is the cyber culture or cyberculture is any culture that has been or is being arises from the use of computer networks for communication, entertainment, and business.

In DOTA 2 uses a sophisticated communication where we can communicate with the players team and our enemies by using a chat room. DOTA 2 is suitable where the cyberculture that which includes the study of various social phenomena associated with the Internet and new forms of communication bentu other networks like online communities, online multiplayer gaming, networking sosialm texting and all matters relating to privacy and identity formation of the network. Where is perfectly suited to the game DOTA 2.

DOTA 2, DotA is a multiplayer online battle arena game, the sequel to the Defense of the Ancients mod on Warcraft 3: Reign of Chaos and Warcraft 3: The Frozen Throne. DotA developed by Valve Corporation, published July 2013 DotA can be played for free on the operation system of Microsoft Windows, OS X and Linux. DotA can be played exclusively through authorized distributor valve, Steam.

DOTA is played by two teams who membered 5 players, each team has its headquarter located in the corner of a map, the headquarters of one building named "Ancient", where the team had tried to destroy the "Ancient" other teams in order to win the game. Each player controls one character "Hero" which focuses on raising levels, collect gold, buy the item and against the other team to win. Phenomenology Alfred Schutz, According to Husserl, through phenomenology, we can learn about the types of experience standpoint the person experiencing it directly as if we experienced it myself [1].

The Social Construction of Reality, Peter L. Berger and Thomas Luckmann first introduced the term construction of reality in 1966 with his book The Social Construction of Reality: A Treatise in the Sociological of Knowledge. They describe the social process through action and interaction, where people are intensely created a reality that is owned and subjectively experienced together.[2] 
Berger is the main thesis of man and society is the product of a dialectical, dynamic, and plural continuously. Society is nothing but a human product, but constantly have back action against the producer. On the contrary, man is the result or product of society. Someone had become a person whose identity so far as it stays in the community. The dialectical process has three stages-Berger called it a moment.

One of them is Internalization. The internalization process is more a re-absorption into the consciousness of the objective world in a way that subektif individuals affected by the structure of the social world. Various elements of the world that has terobjektifkan will be captured as a symptom of reality outside consciousness, as well as an internal phenomenon of consciousness. Through internalization, man becomes the result of the public.

Emotional intelligence, Munzert defines intelligence as intellectual attitudes include the speed of answer, penyeleasaian, and the ability to solve problems.. Emotions according to Goleman is essentially the impulse to act, immediately plan to address the issues that have been implanted gradually by evolution.[3] aspects of emotional intelligence by Salovey who put personal intelligence Gardner who sparked aspects of emotional intelligence is Recognizing the emotions of others, Managing emotions, motivating oneself, recognizing emotions in others, build relationships with people others, confidence, curiosity, intention, self-control, connectedness, communication skills, cooperative.

\section{RESEARCH METHOD}

The subjects were DOTA gamers, either a man or a woman. Researchers investigate actions undertaken by gamers. Their motivation to be a player game DOTA 2, The meaning of the game from their point of view, seek to know the advantages of playing DOTA 2 and how gamers communicate with each other to win the game DOTA 2. The study will last for 6 months to gamers DOTA 2 where previous researchers have approached the study subjects.

With a natural setting using qualitative methods. Methods of data collection is done through a process of interpretation and meaning hermeunistik dialectical focused on construction, reconstruction, and the elaboration of a social process [4] .The paradigm used in this study is a constructivist paradigm. The data presented is basically the result of data analysis, the detailed story of informants in accordance with the expression or their view of what their (including the results of observations), without any comment, evaluation and interpretation [4].

\section{RESULTS AND DISCUSSION}

In this study, the data obtained through interviews to several informants that the players Dota 2 is selected in accordance with the discussion of this study, informants amounted to 9 fans. To measure the identity of respondents in this study, researchers need to look at the identity of the informant in a demographic description of the informant, the informant age, profession and gender informant.

In the results and research describe, classify or categorize data have been obtained from interviews with nine informants to determine the motive and the meaning of internalizing factor which internalization factor refers to how emotional intelligence of Gamers DOTA 2 is formed to win the game DOTA 2.

In this section, researchers are trying to describe, classify or categorize data have been obtained from interviews with nine informants for the motive of meaning, social intelligence and communication patterns of the players DOTA 2.

Based on interviews with informants, the researchers found the informant interviews: 
Early Motif grouping informant Playing DOTA 2

\begin{tabular}{ll}
\hline Early motif playing DOTA 2 & \multicolumn{1}{c}{ grouping Informants } \\
\hline Having Fun Motive & $\begin{array}{l}\text { Ganesha Sugiharta, Igor Fadhillah, Irsyad Ikhsan Arrahman, Sobri Wirandi, } \\
\text { Fauzan Rashid, Biyas Trisna Kusuma }\end{array}$ \\
\hline friends Motive & $\begin{array}{l}\text { Ganesha Sugiharta, Yopi Winarko, Muhammad Okky Anggriawan, Biyas Trisna } \\
\text { Kusuma, Novi Karsetio Wibowo, Irsyad Ikhsan Arrahman, Igor Fadhillah, Sobri } \\
\text { Wirandi }\end{array}$ \\
\hline \multicolumn{2}{c}{ Novi Karsetio Wibowo } \\
\hline \multicolumn{1}{c}{ Motif grouping informant Fore Play DOTA 2 } \\
\hline \multicolumn{1}{c}{ Motif Fore play DOTA 2 } & grouping Informants \\
\hline income Motive & Ganesha Sugiharta, Irsyad Ikhsan Arrahman \\
\hline Achievement Motive & Ganesha Sugiharta, Igor Fadhillah, Irsyad Ikhsan Arrahman, Sobri Wirandi, Biyas \\
\hline Game Addict Motive & Fusuma Trisna, Fauzan Rashid \\
\hline Self Existance Motive & Ganesha Sughiharta, Novi Karsetio Wibowo \\
\hline
\end{tabular}

Motif relationship and meaning players DOTA 2

As already described in the findings that there are 9 motif DOTA 2 gamers informant who concluded from interviews with informants. From 9 motif gamers regrouped into motive motive will produce meanings DOTA 2 itself to gamers DOTA 2. Meaning answered by the entire informant is DOTA 2 where gamers can learn about the importance of friends and teamwork into play. It is closely related to the Friends Motive and other motifs where the motif that occurs is still closely associated with the Friends Motive and requires good teamwork.

The second meaning is DOTA 2 gamers as a means to earn by following a competition or selling items used in the game of DOTA 2 where such goods are also much in the interest of DOTA 2 other players. It is also closely related to the Achievement Motive and the Motive Income. This meaning is produced by gamers DOTA 2 because for gamers DOTA 2 is a game played to achieve advances in the play resulting in competition gamers will get to experience and a lot of things including fame, achievement, and of course related to the Income Motive ie revenue such as money and goods used in the game of DOTA 2.

The third meaning that emerges is DOTA 2 is a very interesting game in which gamers will play DOTA 2 DOTA 2 with a long period of time or with another term addiction to playing DOTA 2. This relates to the Game Addict Motive, Achievement Motive and Self Exstence motive. This meaning is generated by gamers DOTA 2 because gamers feel that the DOTA 2 are the goals that gamers set in her to reach attainment within the game which is not achieved when the phase to the informant as gamers will continue to play DOTA 2 until attainment is reached.

Benefits of Playing Shape grouping Informants

\begin{tabular}{ll}
\hline The benefits of playing DOTA 2 & Informant \\
\hline Team Work & $\begin{array}{l}\text { Ganesha Sugiharta, Irsyad Ikhsan Arrahman, Igor Fadhillah, Muhammad Okky } \\
\text { Anggriawan, Fauzan Rashid, Novi Karsetio Wibowo Kusuma Biyas Trisna, Yopi } \\
\text { Winarko }\end{array}$ \\
\hline Patient & $\begin{array}{l}\text { Sobri Wirandi, Muhammad Okky Anggriawan, Irsyad Ikhsan Arrahman, Novi } \\
\text { Karsetio Wibowo, Yopi Winarko }\end{array}$ \\
\hline problem Solving & Muhammad Okky Anggriawan, Novi Karsetio Wibowo Kusuma Biyas Trisna. \\
\hline \multicolumn{2}{c}{ Emotional intelligence is awakened in playing DOTA 2. } \\
\hline $\begin{array}{ll}\text { Emotional Intelligence The } \\
\text { Awakened }\end{array}$ \\
\hline Patient & Ganesha Sugiharta, Irsyad Ikhsan Arrahman, Igor Fadhillah, Yopi Winarko, Sobri \\
& Wirandi, Novi Karsetio Wibowo, Fauzan Rashid \\
\hline Praise & Ganesha Sugiharta, Muhammad Okky Anggriawan, Yopi Winarko, Sobri Wirandi \\
\hline
\end{tabular}




\begin{tabular}{ll}
\hline Understanding & Ganesha Sugiharta, Muhammad Okky Anggriawan, Biyas Kusuma Trisna, Yopi \\
& Winarko \\
\hline Good Communication & Ganesha Sugiharta, Irsyad Ikhsan Arrahman, Igor Fadhillah, Muhammad Okky \\
& Anggriawan, Biyas Kusuma Trisna, Yopi Winarko, Sobri Wirandi, Novi Karsetio \\
& Wibowo, Fauzan Rashid \\
\hline Believe & Ganesha Sugiharta, Igor Fadhillah, Muhammad Okky Anggriawan, Fauzan Rashid \\
\hline Support & Muhammad Okky Anggriawan, Biyas Kusuma Trisna, Sobri Wirandi, Novi Karsetio \\
& Wibowo, Fauzan Rashid. \\
\hline
\end{tabular}

The results of the analysis of each informant interviews can be categorized for factors that affect communication between game players are

1) Team Work in communication when playing DOTA 2

In-DOTA 2 players can not work alone without a good team and no team able to work with. The need for good communication among team members, for synchronizing strategy and thinking each team. Although already strategizing but when the game is running, things will change because of the pressures experienced during the game. Games DOTA 2 will tend to depress the player with the game system. So the team will be challenged to continuously compact and communicate well with each strategy. Without good teamwork, it is difficult to be able to synchronize everything when the game DOTA 2 runs.

"Teamwork is important, especially if we are working in a team, if anyone hiding or feeling what if later could explode continued to impact on the team. So we can learn teamwork teamwork of playing DOTA 2's. Yes it is that in the team was really open and teamwork really need, just when reprimanded in the forum so already common for our first game also not always in top condition right ".(Interview with Ganesha Sugiharta 17-01-18).

Teamwork benefits gained through playing DOTA 2 is very beneficial for learning will informant due to teamwork, they can apply it in everyday life, especially in the field of employment. They can learn to be working in a team, discuss well with colleagues and become a person who easily accept the opinions of others[5].

2)Patient and Problem Solving

Be patient in the game DOTA 2 is wherein when the informant suffered defeat in the game and then the informant must be patient and refrain informants to remain calm and try in the next game to clinch victory. According to the informant that the informant errors team members must keep thinking of changing strategies to twist the situation and they may require more patience. "Its realization that I take thoroughness in doing something and wait in any case".(Interview with Sobri Wirandi 17-01-18).

For the informants benefit from this patience can they be applied in everyday life where the informant to be more patient and meticulous in doing everything. The benefits of patience is also related to the Problem Solving, or solve problems. Informants find benefit in solving the problem of playing DOTA 2. When the strategy fails then the informant should be extra thinking to reverse the situation and to make the strategy eventually succeeded and the issue finally be resolved[6]. Then the informant resolve internal problems such as the problem with the team is the most important thing which the informant was often argued because experienced a communication error while playing DOTA 2.

3) Skill (Ability to play)

Skill or ability to play DOTA 2 obtained by the informant. It is concerned with how the informant enter the competition DOTA 2 and in getting goods that can be sold to other players, informants also improve the routine of the game where the more they play a growing ability of the players to play DOTA 2 DOTA 2. 
"Getting new friends, plus rooster and i can get other advantages benefit like rich money or items in DOTA 2 if I win the competition". (Interview with Novi Karsetio Wibowo, 13-0118).

The players in the online game would prefer a player with the ability to play that is already good [5].It is also intertwined with the many new people encountered by gamers DOTA 2 wherein DOTA 2 is a game that is known by the online-based game where people can meet people anywhere dibelahan this world. The informant was able to get to know many new people which has never been previously encountered by informants in a place that has not been visited by the informant is an advantage in getting through the game DOTA 2. DOTA 2

Social and Emotional Intelligence construction that is built to play and win the game

The Social Construction of Reality (Social Construction of Reality) is defined as a social process through action and interaction in which the individual or group of individuals, constantly creating a reality that is owned and subjectively experienced together. Berger and Luckman believes that public institutions are created and maintained or changed through human action and interaction, although society and social institutions objectively evident, but in fact all formed in the subjective definition through interaction process. Berger \& Luckmann argued that reality is socially constructed, in terms of the individuals in the community who have built a society, it is the individual experience can not be separated with the community.

In playing DOTA 2 DOTA 2 players get internalisation factors that constitute Emotional Intelligence is awakened in playing DOTA 2. In carrying out communication activities, a person is required to accept, assess, manage, and control the emotions himself and others around him to avoid conflicts which could undermine the purpose of communication is understanding the meaning [7]. In this case then demanded their emotional intelligence (emotional quotient / EQ). Emotional intelligence now considered more important than mere intellectual acumen in contributing to the success of a person.

Intelligence quotient is high if not accompanied by high emotional intelligence will lead to emotional instability, irritability and drive errors in determining and solving the problems of life as it hampers one's concentration. Meanwhile, people who have high emotional intelligence are trying to create a balance of self and the environment, trying to achieve happiness and can change or fix a bad thing for the better. People with high emotional intelligence cenderng also able to work as a team with a variety of other people who have diverse backgrounds. In other words, the emotional kecerdasaran seen from the behavior exhibited by a person in a social activity or akfitias with others.

In winning the game DOTA 2, researchers found that emotional intelligence affects the players to be able to win the game. The game not only can win by playing ability (skill) DOTA 2 good players, but with good teamwork. Teamwork good and is supported by emotional intelligence is awakened by the player / Gamers DOTA 2.

Factors emotional intelligence is awakened is a very important factor to be able to get kemanangan in play DOTA 2. And it is:

1)Patient (Patience) player in building social intelligence.

cited by Goleman [3], factors Emotional intelligence by Salovey one of which is to Recognize Emotional Self. Recognizing emotions themselves is an ability to recognize the feelings of feeling when it happens. This ability is the basis of emotional intelligence, psychologists mention self-awareness as metamood, which would be his own emotions a person's consciousness. According to Mayer [3] of self-consciousness is alert to the mood and thoughts of mood, when less vigilant then the individual becomes soluble in emotional flow and 
controlled by emotion. Self-awareness does not guarantee mastery of emotion, but it is one important prerequisite for controlling emotions so that people easily master the emotions.

"There is usually one of my team colleagues are reminded to remain calm, and I became calm again. I need to trust each other at frequent communication. ".(Interview with Igor Fadhillah 10-01-18).

Patience in this case so is related to how to win the game DOTA 2 can be achieved. According to the informant Ershad Arrahman Ikhsan, patience is important in because to remain patient, the player will remain stable in terms of emotional and players will still produce a good performance. By playing in a state of good performance of the winnings will be easier to obtain.[6]

2)Praise (Praise) player in building social intelligence.

The ability to recognize the emotions of others is also called empathy. According to Goleman [3] the person's ability to recognize another person or matter, demonstrate the ability of one's empathy. Individuals who have the capacity for empathy is able to capture the social signals that suggests hidden anything needed other people so he is more able to accept the other person's perspective, sensitive to the feelings of others and more able to listen to others.

"Actually it's a good team is a team that can communicate well the which is one of those teams do kill, to kill or support we need to praise him, he appreciated his moral order form. Meanwhile, if the team that his communication ugly, trashtalk, grumbling was going to hell can not prevail because he guns thinking about his team. ".(Interview with Muhammad Okky Anggriawan 10-12-17).

Praise is important in playing DOTA 2 to support teamwork or cooperation team to win DOTA 2. Cooperation team is not only a good play. Playing well in a game system that performed together requires good communication and empathy. [7] Praise is expected to improve the performance of the well each player to be among the players in a team. Players will feel more appreciated each other and the performance will be better and easier to win with such a good performance.

3) Understanding (Understanding) player in building social intelligence.

Nowicki, psychologists explain that children who can not read or express emotions well will continually frustrated [3] .Someone who is able to read the emotions of other people also have high self-awareness. Increasingly able to open his own emotions, able to recognize and acknowledge his own emotions, then that person has the ability to read other people's feelings.

"There is usually one of my team colleagues are reminded to remain calm, and I became calm again. We need to trust each other at frequent communication. ".(Interview with Igor Fadhillah 10-01-18). Each player DOTA 2 departs from each of the different personalities that make one team has the properties and characteristics of different. The nature and characteristics of the different makes and how to play each player play patterns were different [6]. DOTA 2 Players must think of to give each other mutual understanding to fellow members of the team to get a solution amid these differences. Igor informant Fadhillah for mutual understanding and gave sense is the most important thing to keep compactness. With adequate communication by utilizing the features of the player chat or voice chat to communicate the strategy and solution to the various problems that will be faced by the players DOTA 2 .

4)Good Communication (Communication was good) player in building social intelligence. Ability to build relationships is a skill that supports popularity, leadership and interpersonal success [3]. Skills in communicating the basic skills in successful relationships. Individuals difficult to get what he wants and it is also hard to understand the desires and wishes of others. "Actually it's a good team is a team that can communicate well the which is one of those teams do kill, to kill or support we need to praise him, he appreciated his moral order 
form. Meanwhile, if the team that his communication ugly, trashtalk, grumbling was going to hell can not win because he's thinking about his team guns. (Interview with Muhammad Okky Anggriawan 10-12-17). Differences every characteristic of the players in the game play DOTA 2 create new problems where communication becomes difficult to understand. The limitations of language or difficulty split time between playing and communicating via chat or voice chat feature. It is indeed a problem. Fostering good communication is essential for the players to get a conclusion how the game can be won.[8]

5)Believe (Believe) player in building social intelligence.

Having team members who are not always in the same place when playing DOTA 2 is a problem that is quite crucial. Where the communication interface limitations can not be done. This is a challenge for the players DOTA 2 from being dissolved into the problems that hinder them in getting the victory in the play DOTA 2. By utilizing the chat and voice chat features in DOTA 2 DOTA 2 players to maximize her to communicate well and provides insight and understanding the condition of his team in order to play well and create good susana that team performance is maintained. "There is usually one of my team colleagues are reminded to remain calm, and I became calm again. We need to trust each other at frequent communication. ".(Interview with Igor Fadhillah 10-01-18). The rest of each team will provide confidence in the members of his team to stay on strategy for the limitations in providing a signal when there is a change in strategy can be resolved by believing in the ability of each team in the reading of the situation in the game. If trust is not awakened, then each player in the team will perform actions that would jeopardize the team and it can result in losses. [9].

6)Support (Support) The player in building social intelligence.

Ability to build relationships is a skill that supports popularity, leadership and interpersonal success[3]. Skills in communicating the basic skills in successful relationships. Individuals difficult to get what he wants and it is also hard to understand the desires and wishes of others. [10]. Of course, in playing DOTA 2 is the most important component of good teamwork. In the play DOTA 2 are tasks that must be implemented in a team. Where the task in a team in need of support or support to the team so that the game can run well. It would be more useful and more totality of the game so that other players can easily be helped by the support of the team members who served as Supportfor Support will always support and help members of the team despite Support must sacrifice himself for the safety of friends team. Controlling emotions in play DOTA 2 is important. "Meanwhile, his communication team ugly, trashtalk, grumbling was going to hell can not prevail because he guns thinking about his team.".(Interview with Muhammad Okky Anggriawan 10-12-17).

7) Intersubjectivity of the game DOTA 2

Intersubjective experience DOTA 2 gamers informants about how they ended up choosing DOTA 2 to be played is how friends are the most important factors for the informant to start start the game DOTA 2. For the informants DOTA 2 is about teamwork where when with friends would be more comfortable informants and informant no need to adjust. As explained in the research results obtained by the informant in In Order Motive (Motives for), Informant also has the objective is to earn money, to win the competition, because of his penchant to play, and the presence of factors informant who wanted to be recognized by the environment. Where in earning in-game DOTA 2 is described by the informant Fauzan Rashid that in playing DOTA 2 DOTA 2 players including himself is eyeing a significant development in DOTA 2, and these developments should be accompanied by a consistent victory. Fauzan also recognizes that every game can not continue to win and he believes that there are in every game defeat. All the dynamics of the motives and goals of informants related to the influence 
of friends in this team playing together informants to mengapai their goal to win the game and eventually form a pattern of the same experience [11].

\section{CONCLUSIONS}

As explained at the outset that this study discusses how Construction of communication Construction Communication Between Players In Game Winning the game in the game DOTA 2 using Phenomenology of Social aims to find out how the construction of communication between game players in online games (dota 2), Factors anything that affects communication between game players in team work (teamwork), Gamers experience in winning games, and know the motive and meaning of Gamers in game play DOTA 2 and win the game.

Social Construction and Communication Patterns DOTA 2. Internalization: Where emotional intelligence informant awakened. one's ability to recognize emotions, managing emotions, motivating oneself, recognizing emotions in others (empathy) and the ability to build relationships (in cooperation) with other people. Informants felt that the team understand each other shortcomings and always believed in the ability of each team is a good way to get fluency in game play DOTA 2. Always communicate well and focus on playing well be something that helps to smooth game play DOTA 2 and will be easier to win the game. Where patience is needed, teamwork is equally important and also the ability to solve problems. In DOTA 2 is not only a team leader who determines the course of the game and it shall decide how the game goes. But every member of the team is very influential in the game where no communication is done by each member of the team will be led to the defeat and where every communication is useful to disclose the information about the strategy of the opponent team.Gamers experience in winning Game

Informants revealed that the informants did not start DOTA 2 by way of professional gamers. Informants departing from a player who has a motive to play for fun play with his friends. Then over time and the intensity of their play increased informants become familiar with their competitions and events held by many who use the game DOTA 2.

Plus with features called DOTA 2 MMR which make gamers DOTA 2 becomes increasingly happy to play in order to get a high score. Since then the informant a lot of practice to be the best and earn profits. In acquiring these things with a high intensity game makes informant has the ability to play very well in every game that informants play.

Motif informant playing DOTA 2 are : Having fun, friends, self Existence, Game Addict $\&$ Achievement, income meaning of DOTA 2 for informants are : Friends, gamers learn the importance of teamwork with team members, Achievement, gamers get a lot of getting experience of winning the competition and benefit from it. Gamers also learn to reach the goals that have in her life.

\section{REFERENCES}

[1] E. Kuswarno, "Metodelogi Penelitian Komunikasi Fenomenologi: KOnsepsi, Pedoman dan Contoh Penelitian," no. 56, p. VIII + 264, 2009.

[2] M. S. Ahluwalia et al., “No Title肯定 ・否定表現における日本語程度副詞について ," IOSR J. Econ. Financ., vol. 3, no. 1, p. 56, 2016.

[3] D. Goleman, "Emotional Intelligence: Why EI is more important than IQ, trans. T. Hermaya. Jakarta: Gramedia Pustaka Utama, 2001.,”p. 2001, 2001.

[4] D. Hertanto et al., "Abdul Malik dan Aris Dwi Nugroho Pendahuluan Ragam Paradigma," Habitat, vol. 29, no. 2, pp. 55-65, 2016. 
[5] Y. Kou and B. Nardi, "Regulating Anti-Social Behavior on the Internet: The Example of League of Legends," iConference 2013 Proc., no. 2011, pp. 616-622, 2013.

[6] R. A. Darmawan, "PEMAKNAAN GAME ONLINE DOTA 2," vol. 2, no. 2, pp. $2197-$ 2203, 2015.

[7] Y. Kou and X. Gui, "Playing with strangers: Understanding temporary teams in league of legends,” CHI Play 2014 - Proc. 2014 Annu. Symp. Comput. Interact. Play, pp. 161$169,2014$.

[8] Chih-Chien Wang and Chia-Hsin Wang. (2008), "Helping Others in Online Games: Prosocial Behavior in Cyberspace. Journal of CyberPsychology \& Behavior 11, 3: 344346. http://doi.org/10.1089/cpb.2007.0045," Cell, vol. 151, no. 4, pp. 1-46, 2008.

[9] N. Yee, "Motivations for play in online games," Cyberpsychology Behav., vol. 9, no. 6, pp. 772-775, 2006.

[10] S. Malisi, S. Suharsono, and S. Setiawan, "Language and Identity in Online Gamer Community," J. English Lang. Lit., vol. 8, no. 2, p. 617, 2017.

[11] N.K. Juliantari, I.K. Sudarsana, N.K. Sutriyanti, I.N.T. Astawa, I.D.A.H. Putri, and K. Saddhono. "Educational Games Based in Information Technology as Innovation Evaluation Activity in Learning." In IOP Journal of Physics: Conference Series, vol. 1114 no. 1, p. 012041 . IOP Publishing, 2018. 